\title{
Black theology in South Africa - A theology of human dignity and black identity
}

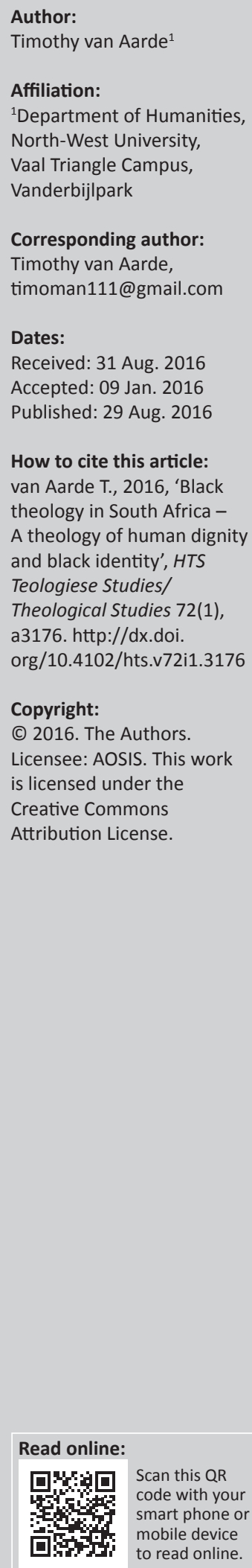

Black theology in South Africa is still relevant 20 years after the apartheid regime ended. It is a theology that gave to Black South Africans human dignity and a black identity. Black theology in South Africa confronted the imbalances of power and abusive power structures through an affirmation of human dignity and the uniqueness of the identity of black people. The biblical narrative of the Exodus is a definitive narrative in American black theology and liberation theology in overcoming oppression understood as political victimisation. Black theology in South Africa is not primarily about power and economics but also about the rediscovery of human dignity and black identity and to a lesser extent about victimisation. A third generation of black theology in South Africa will gain impetus through a rediscovery of human dignity and identity as its core values instead of a Black American liberation theology of victimisation or a Marxist liberation theology of the eradication of all power or economic imbalances.

\section{Introduction}

The emerging post-Cold War and post-apartheid paradigm of black theology performs a unique role in reaffirming the human dignity of Africans and their black identity. The 'caricature was a byproduct [sic] of the apartheid culture was that blacks lost their human dignity and identity' (Du Toit 2008:34). It is the contribution of black theology to the affirmation of the dignity of Africans and their identity which is the inherent and continued contribution of the theology. Black theology in South Africa is a contextual theology that engages current political powers and structures from an African context and is in this sense distinct from American black theology and liberation theology, which has its roots in Latin America. ${ }^{1}$ Black theology in South Africa was born in the context of the South African liberation struggle; it is synonymous with the apartheid struggle. It was a black consciousness movement that affirmed the dignity of South Africans and their history, and also helped them rediscover their identity. ${ }^{2}$ It is an interpretation of American black theology that is honestly and authentically an African black experience within the complexity of the meaning of blackness in South Africa. ${ }^{3}$ Black theology in South Africa has consisted of two waves. The first 'wave' was built on the foundations of black consciousness laid by Steve Biko: ${ }^{4}$

All in all the black person had become a shell, a shadow of man, completely defeated, drowned in his own misery, a slave, an ox bearing the yoke of oppression with sheepish timidity. In response, the black consciousness movement helped black people to find their identity in themselves. (Ndalamba 2010:27)

According to Kee, '[t]he second wave of black theology in South Africa is best represented in the work of Allen Boesak' (2008:79). The agenda for a third wave ${ }^{5}$ was set in the 1980s by the 'Black theology project' and the significant article, 'Black theology and authority' contributed by Mokgethi Motlhabi. ${ }^{6}$ The agenda set by Motlhabi has still to be kick-started and given the necessary impetus and momentum for there to be a third wave of South African black theology. This article makes the contribution that human dignity, to which identity is to be added, can provide the impetus for such a third wave of black theology in South Africa.

1.African Americans were not really clear about their real status and identity in their own country (cf Motlhabi 2009:176).

2.The apartheid government blatantly disregarded the humanity and human dignity of black people in South Africa (cf Motlhabi 2008:175). 3.See Pinn 1998.

4.Black consciousness takes what he refers to as 'cognisance of the deliberateness of God's plan in creating black people black' (Biko 1978:49).

5.The first wave of black theology is identifiable with Malcom X's proclamation in the 1950s and Dr Martin Luther King. The second wave of black theology was its 1960 s roots in civil rights activism and James Cone, who identified it with liberation theology. Cone was the founder of black liberation theology. He identified the overriding message of the OT prophets as a condemnation of the nation of Israel founder of black liberation theology. He identified the overriding message of the OT prophets as a condemnation of the nation of lsrael
and of the religious establishment for oppressing the poor. The third wave of black theology includes black feminism and black womanist identity, and has addressed the inadequacy of black theology and its inseparable relation of race and class to include also the womanist identity, and has addressed the inadequacy of black theology and its inseparable re
realities of gender bias and other factors endemic to human culture of the past and present.

6.Mokgethi Motlhabi was originally a candidate for the Catholic priesthood, who became the director of the black theology project when Ntwasa was banned (cf Kee 2008:85). 


\section{The roots of black theology in South Africa}

\section{The black consciousness of Steve Biko}

There is an important question to ask: 'Is black theology in South Africa a sibling of American black theology or a more distant relative?' Says Kee: 'Black theology is set in the wider context of the worldwide struggle for liberation' (2008:84). In South Africa the umbilical cord of black theology was American black theology and liberation theology, and as it has come of age it has become not simply a church for Africa but a church of Africa (cf Boesak 1978:75) with its own authentic black expression of Christian faith (cf Boesak 1978:56). It is the foundation laid by $\mathrm{Biko}^{7}$ and later by Boesak that gave to black theology in South Africa its unique place and set it apart from South American liberation theology (cf Boesak 1978:70). Biko laid the foundations for a strong grassroots black consciousness in which blacks could learn to assert themselves and stake their rightful claim. 'Black consciousness instils a critical attitude towards the world and the way it undermines personal identity, well-being and human dignity' (Du Toit 2008:33). It began with an awakening of a black consciousness, with self-affirmation and the reevaluation of relationships with whites. 'Black consciousness did not evolve in isolation, however, but should be viewed in conjunction with black power, black nationalism, black identity, racial nationalism and racial internationalism' (Du Toit 2008:31). The idea behind the black consciousness of Biko was the assertion of the dignity and identity of blacks. It was the rediscovery of the dignity and identity of Africans as being central to the black consciousness of Biko that set it apart from its American counterpart in the complexity of the integration process. ${ }^{8}$ In Woods' (1987) view:

[t]he idea behind black consciousness was to break away almost entirely from past black attitudes to the liberation struggle and to set a new style of self-reliance and dignity for blacks as a psychological attitude leading to new initiatives. (p. 33)

What made Biko's black consciousness 'stand out was his invocation of certain values underlying the struggle humanity, identity, self-respect, trust in oneself, responsibility, pathos, to name but a few' (Du Toit 2008:32). ${ }^{9}$ Under the apartheid system black South Africans were robbed of their human dignity, identity and human rights (cf Du Toit 2008:32).

\section{The contribution of Allen Boesak to a South African black theology}

The African scholar Mbiti (1969) saw black theology as a purely American phenomenon concerned with American social problems without recognising the possibility of the contextual transposition ${ }^{10}$ of black theology to new contexts

7. Black consciousness seeks to "infuse the black community with a new-found pride in themselves, their efforts, their value systems, their culture, their religion and their outlook to life' (Biko 1978:49)

8.'Its ultimate aim was to produce 'real black people who do not regard themselves as appendages to white society' (Biko 2004:55, in Du Toit 2008:33).

9.Assuming responsibility to find identity probably has an individualistic bias (cf Du Toit 2008:31).

10.Black theology is a 'contextual theology' (Boesak 1984:61). such as South Africa, giving birth to a distinct strand of black theology. ${ }^{11}$ South African black theology is not a homogenous theological movement. In the case of South African theology, Biko put the accent squarely on African culture, which is made up of many diverse elements and a diversity of cultural expressions. ${ }^{12} \mathrm{He}$ 'turned to African culture for a retrieval of black identity' (Du Toit 2008:35). ${ }^{13}$ Moore (1973:5) believed that black theology is what he called a 'situational theology', and in the case of South Africa blacks are not a homogenous group but coexist in a multiplicity of situations. ${ }^{14} \mathrm{He}$ tried to understand as clearly as possible who these people were, what their life experiences were, and the nature and cause of their suffering which constituted the essence of an African identity. Black theology in South Africa's roots is that each ethnic group had to be able to attain its style of existence without the fear and threat of loss of culture in relation to the other. ${ }^{15}$

The vision of Nelson Mandela of a rainbow nation was grounded in the mutual respect groups have for the culture and language of one another in South Africa. It was a vision of the harmonious co-existence of diverse ethnicities born out of the struggle in which Africans were robbed of their dignity and African identity. The apartheid ideology imposed geographical boundaries of separation in order to maintain ethnic identity. It was out of this mutual respect for one another's complete freedom of self-determination ${ }^{16}$ that Biko argued that a genuine fusion of the lifestyles of the various groups would arise. The multiracial character of black theology in South Africa is attributable to Boesak: he insisted that Coloureds be included. He did not advocate an American black theology that cast itself as a purely black-white struggle. The essence of the black theology that developed in South Africa was a struggle for human dignity, what it means to be human, and an identity which clearly set it apart from its American counterpart that focused on what it meant to be black. ${ }^{17}$ The fundamental criticism levelled against American black theology is that it had lost its sense of what it meant to be African. It came to play its drum to a victimisation mindset as it was not anchored in its God-given and -created African cultural roots.

The black consciousness of Biko instilled a critical attitude towards the world and the way it undermines personal identity, well-being and human dignity (cf Du Toit 2008:33). It developed in a different direction from the American black theology. Central to this was the idea of Stevo Biko that blacks

11.Two strands of black theology are identifiable, one which excludes whites and the other which includes them.

12.Biko saw community identity as the hallmark of an African culture (cf Du Toit 2008:31) distinct from the individualistic identity of American black culture.

13.The strategy of Biko was to promote African culture, languages and religions (cf Du Toit 2008:35).

14.The vision of a Rainbow Nation has its origins in mutual respect for one another's complete freedom and the self-determination of Biko.

15.'Black consciousness is intimately linked with the importance of dignity in African culture' (Du Toit 2008:35).

16.The term 'self-determination' is more comprehensive and reflective of Biko's black consciousness than the 'self-responsibility' identified by Du Toit (2008:28-52). 'Self-responsibility' is one of the essential constitutents of 'self-determination'.

17.'The fact that apartheid was open and legislated racism whereas American democracy fell short of its claims as far as black people were concerned is a good illustration of one of the concrete differences in the two situations' (Motlhabi 2008:176). 
have allowed evil to reign supreme by recognising that black people were not innocent victims. Boesak took this further and called it a 'pseudo-gospel'. It developed in a direction expressed by clichés such as 'Black is beautiful' in the context of a white-black society in America and in South Africa it developed according to its African context expressed by sentiments such as 'African is beautiful'. It was Mbiti's unfamiliarity with the South African context that led him to see South African black theology as 'purely an American phenomenon' (Motlhabi 2008:9). It is necessary to understand that apartheid ideology necessitated a unique response in the form of a black theology. The ideological distinctions between white and African cultures placed the stress upon the cultural distinctions among African ethnic identities and upon separate linguistic and racial groups. It was capitalised upon and given as proof of the existence of not only different but also irreconcilable differences (cf Motlhabi 2008:9).

Apartheid was motivated by the view that different African ethnicities need to be kept apart for their own protection. It was a system that focused on the creation and maintenance of artificial differences between ethnicities. As long as distinctions between ethnicities could be maintained, apartheid seemed to be a justifiable solution. It is as if identity is determined by one's race - 'racial identity', as identified by Boesak (1984:114) - and it is permitted to 'determine everything else in a person's life with an overwhelming intensity' (Boesak 1984:114), leading to the image of God and human dignity being undermined and trampled underfoot (cf Boesak 1984:104). ${ }^{18}$

\section{The parting of the ways of South African and American black theology}

Boesak's criticism of American black theology was that it was influenced by the ideology of black power and he rejected it as a secular movement that had no faith in love and so it had failed to display the Christian insights of Martin Luther (cf Kee 2008:84). His criticism of American black theology was also that of Martin Luther King that 'love is identified with a resignation of power and power with a denial of love' (King 1976:43, in Kee 2008:84). He identified the 'stubborn refusal to respect the dignity of Black personhood' (Boesak 1984:87) as the central problem of South African society.

For Boesak, a critical distance existed between African and American black theology; for him, the criticism of American black theology is that 'it is a contextual theology which has only a shallow understanding of the context and consequently only a limited vision of the task' (Kee 2008:83). The second criticism is that American black theologians 'generalise their analysis of their situation, as if it were the norm for all black [people] throughout the world' (Kee 2008:83). Kee continues:

Boesak was influenced by American black theology but he retains a South African perspective which make [sic] him deeply critical of the assumptions, values and aspirations of the American form. (2008:82)

18.For Boesak (1984:62), the breaking down of the wall of partition in Christ makes possible a country where all its citizens live in peace together.
For Boesak, American black theology tended to become narrow, blinkered and self-obsessed. It has a thin conception of black identity, as stated by Shelby (2001):

The prevailing thin conception of black identity in the United States holds that blacks are those people who have such inherited physical traits as dark skin, tightly curled or 'kinky' hair, a broad flat nose, and thick lips, and/or those persons who are descendants of people that are presumed to have such characteristics. (p. 239) ${ }^{19}$

A thin conception of black identity requires more than a common physical appearance or shared ancestry (cf Shelby 2001:240). Thick identity is tied neither to 'race' nor to biological ancestry (cf Shelby 2001:241). A collective black identity is an absolute prerequisite for black solidarity (cf Shelby 2001:243).

\section{Parting of the ways of black theology and liberation theology Black theology and liberation theology}

Black theology in South Africa was instrumental not only in ending the structural sin of apartheid but also in the development of a national reconciliation that led to the building of a new South Africa. Black theology has a role to play in the rethinking of an African theology. Buthelezi (1974) wrote an article entitled 'An African theology or a black theology?' in which he explained the different departures of an African theology and black theology. Black theology in South Africa developed uniquely and faced different struggles than elsewhere, for instance South America and the struggle for liberation, North America and the emancipation of American blacks. Mbiti (1969), however, argues that no distinction should be made between Black theology and an African theology. His analysis is that black theology is African theology and African theology is black theology (cf Motlhabi 2008:178). Although black theology is an African theology, African theology is not necessarily per se a black theology which affirms the assertion that South African black theology is a unique black theology distinct from American black theology. ${ }^{20}$ For Mbiti, black theology stands in a continuity with Latin American liberation theology, which is a theology of conflict on behalf of the poor and the marginalised (1974:41-44). Mbiti writes, 'Black theology hardly knows the situation of Christian living in Africa, and therefore its relevance for Africa is either non-existent or only accidental' (Mbiti 1974:43). Black theology in South Africa is a grassroots ${ }^{21}$ theology that does not simply act on behalf of the poor and the marginalised but draws the poor and the marginalised into the struggle on the grounds of human dignity and black identity.

19.Thin black identity is expressed in terms of the racialist view or the ethnic view (cf Shelby 2001:241).

20.'The preoccupation of American black theology with liberation theology from racial oppression limited its relevance outside the Republic of South Africa' (Pobee 1979:38-39).

21.It has been suggested that black theology was not acclaimed as grassroots theology as most of its activities were centred in institutions of higher learning; and rarely was it the subject of the 'pulpit' because mainline churches were either suspicious was it the subject of the 'pulpit' because mainline churches were either suspicious
or held in check by the 'missionary eye of learned', and attempts to engage grassroots were problematic. 
Black theology in South Africa was part of an ongoing movement of liberation and not simply a transposition of South American liberation theology. A new agenda was set for black theology against the background of an African context. In terms of the broader context it was part of liberation theology, but in its specific context it was a uniquely South African theology. Boesak used the language borrowed from the liberation theology of 'the oppressed' and 'oppressor', but he avoided the stigma of victimisation associated with these terms by asserting that the oppressed are not absolved and innocent. This is a perception of victimisation that engenders powerlessness, weakness and helplessness (cf Boesak 1978:3):

It effectively blocks off all awareness and therefore the sense of responsibility necessary to confront the other as a human being. This leads to an inability to repent which in turn makes genuine reconciliation impossible. (Boesak 1978:4)

He developed the thought of Biko that 'the most potent weapon in the hands of the oppressor is the mind of the oppressed' and made the statement that 'the greatest ally of the oppressor is the mind of the oppressed' (Boesak 1978:6, in Kee 2008:81). Boesak did not travel down the road of mainstream liberation theology in which the black people of South Africa are regarded as having been oppressed and are helpless and innocent victims. Whereas Biko turned to African culture for a retrieval of black identity, Boesak turned to the gospel for black identity. ${ }^{22}$ For Boesak the dignity of man was founded upon man being made in the image of God.

\section{The reclamation of victimisation}

Maria del Guadalupe Davidson (2006) has developed the idea of the 'reclamation of victimisation'. 'The reclamation of victimisation argues that victims can gain affirming identity reclaiming and renaming their past pain and using it to create a better self' (Davidson 2006:15). Her idea of the reclamation of victimisation does not blame or absolve white racism as she sees 'blaming' as externally focused: 'The reclamation of victimisation calls for turning inward of black identity to speak to itself about itself' (Davidson 2006:15-16). Her contention is that affirming black identity must speak to its own painful history but not be constituted as a victim by others' (Davidson 2006:16). She asserts that 'the positive tension between past and present is a marker of revolutionary black identity' (Davidson 2006:16).

Biko and Boesak did not approach the past through the lens of psychology but theologically. The reclaiming of victimisation requires invoking the theological building blocks of repentance because the oppressed are not absolved from innocence and so they are victims. Repentence is the recognition by the oppressed of having allowed themselves to become victimised. It is a part of overcoming the self-perception of being a victim. It was repentance by the oppressed for having allowed themselves to be oppressed that created the space for the oppressors to be 22. Black Christians understand and interpret their situation in the light of the gospe of Jesus Christ (cf Boesak 1984:60). confronted with the guilt of their oppression - and that brought about the demise of apartheid. The repentance exercised by Biko and Boesak took this form: recognition of the justification of the oppression by the complacency of the oppressed in passively accepting their situation..$^{23}$ Repentance is the first step in the process of liberation from a slave mentality. It opens up the space for the oppressor to repent, which makes genuine reconciliation possible. According to Boesak, 'Black theology offers reconciliation and peace in a situation where citizens do not trust each other, where we have been driven apart by laws, and where we are kept apart by fear and hatred' (1984:62).

Boesak departed from liberation theology in terms of a second important trajectory. The liberation theology of Gutiérrez focuses on the liberation of people from oppressive structures and places the emphasis on liberation and freedom as the ultimate goal. For Boesak, the focus was not primarily about liberation from oppressive structures but a rediscovery of human dignity and identity. Freedom without dignity and identity is no freedom at all; in fact, it is another form of bondage. Liberation and freedom are about emancipation and limit future possibilities, whereas human dignity and identity, respect for ourselves, and knowing who we are and where we have come from open up new possibilities for the future. Liberation and freedom without human dignity and identity is a 'pseudo-freedom', as Boesak calls it. For Gutiérrez, a man has to liberate himself from all that limits and keeps him from self-fulfilment and also from all impediments to the exercise of his freedom. ${ }^{24}$ Liberation and freedom are of paramount importance in liberation theology, which is therefore negatively oriented. It has as its agenda revolution: confronting the power structures of society. It weds the biblical message and aspects of Christian thought and practice with Marxist theory. ${ }^{25}$ In contrast, black theology is positive: 'It speaks of Christian hope where so many have lost all hope' (Boesak 1984:62). It confronts the imbalances of power and abusive power structures, but it does so in order to restore human dignity and identity, which is true freedom. The quest for true freedom in black theology leads to the creation of a new man $^{26}$ and a qualitatively different outcome from the avocation of freedom by liberation theology. The source of the creation of the new man for Boesak is not found in liberation or freedom: he is insistent that black theology itself falls under the judgement of the Word. Black experience and the black situation alone do not have revelation value on a par with the scriptures. Boesak writes: 'The black experience provides the framework within which blacks understand the revelation of God in Jesus Christ. No more, no less' (Boesak 1978:12). Following this, the oppressed can adopt the role of the oppressors if liberation or freedom is their sole aim. In the African context, the white colonial rulers have been replaced

23. Cornel West criticises black liberals' use of victimisation by stating that it 'adhere [s] to a victim-status conception of black people that results in blaming all personal failings of black people on white racism' (West 1982:75).

24.For Gutiérrez, liberation is the instrument of self-fulfilment, whereas for Biko and Boesak dignity and identity bring about self-fulfilment.

25.'We wish to hear a word from the Churches relative to what is being done in South Africa: not a word in the name of Marx or Lenin or Stalin or Mao; but, rather, word in the name of Jesus Christ and in the name of the church' (Boesak 1984:143).

26.Biko envisaged a new and renewed humanity. 
by a new black elite: 'The black elite simply crossed the line to join those who held the power and privilege' (Kee 2008:87). The roots of oppression lie deeper than liberation and freedom, the end of apartheid in South Africa. It is about the rediscovery of human dignity and identity so that theology as an African theology still has much to do.

\section{A third wave of black theology in South Africa$$
\text { Racism and the restoration of human dignity }
$$ and black identity}

A third wave of black theology is needed that sets a new agenda for black theology which goes beyond apartheid, race and colour. If Allan Boesak is right and black theology was about much more than ending apartheid and racialism and was part of a larger on-going movement, then the rediscovery of human dignity and black identity are central to identifying its role and place in a post-apartheid South Africa. Boesak (1984:55-56) identifies 'human fulfilment and wholeness', humanity and humanness, as core to the gospel truth. He quotes an African proverb in seSotho: Motho ke motho ka batho ba bang - 'I am human only because you are human.' Dignity and identity in South Africa have to be rediscovered in the context of the community in which the value and significance of the other is reaffirmed. He continues: 'Black theology also speaks of the discovery of being a human being' (1984:61), ${ }^{27}$ that is, it is fundamentally about what it means to be human.

'If racism is the agenda,' warns Kee, then black theology becomes redundant with the end of apartheid' (2008:87). Racism is based on identifying characteristics that distinguish different 'races' such as skin colour, eye colour and type of hair, customs, language, religious beliefs and more. Racism was one of the forms or faces of apartheid but its roots lay much deeper. Apartheid was a social construct in which selfapprobation emerged from the negative valuation of the other. It is illogical that racism can only be a personal matter because to make a generalisation requires the presence or consideration of a group; therefore racism is a social matter. Racism as a social system relies on its ability to define the other. ${ }^{28}$ "The act of definition requires the exercise of the power of one group over another' (Nothwehr 2010:119). It is the fact of definition that set up a dependency of blacks on the dominant other - whites - for their social identity that is at the root of the social construction of apartheid. In this regard, Motlhabi asserts: 'Racism as such is not the real poison in inter-personal relations. It is that for which racism exists, that is the vast discrepancies in the distribution of power' (Motlhabi, in Kee 2008:86). Behind the face of apartheid was an authoritarianism and a social structure in which some people regarded themselves as superior. Such people believed they have the right to exercise control over the lives of others by virtue of the position they hold within the social structure. Racism was the legitimation of unequal

27.Apartheid meant that the most important thing about a person was not that he or she was a human being created in the image of God with inalienable rights but his or her racial identity (cf Boesak 1984:114).

28.It is the 'I-Thou' relationship that offers the possibility of human interaction. power relations, of dominance as a relationship that provided a semblance of content for apartheid. It would be superficial to think that the end of apartheid would radically alter relations of power and advantage, because it is through social structures that inequalities in power are perpetuated. It was these power inequalities that perpetuated the institution of apartheid at a deeper ideological level. As Kee puts it: 'In tracing the origin of oppression back to interest and relations of power, black theology roots oppression in the economic base of society' (2008:87). It is the defining of one's own culture as being superior and the other as inferior that provides the rationale and justification for unjust legal, social and political discrimination and oppression. Nothwehr expresses it as follows: 'Racism in the broad sense is selfvaluation through the devaluation of the other' (cf 2010:120), that is, it is based on identifying a particular biological or other characteristic to define the self as superior in relation to the other, who is defined as inferior. In a narrow sense, racism is a focus on biological difference or specific traits that are given to devised paradigms called 'races' (Nothwehr 2010:119-120). 'The particular characteristic defining inferiority and superiority', he maintains, 'are indelibly stamped into the very body of the other and thus cannot be changed through any form of assimilation into the "superior" way of being or culture' (Nothwehr 2010:121). The roots of racism can be overcome only through the restoration of human dignity and black identity. ${ }^{29}$ For black theology in South Africa to recover its loss of black identity, it will require a collective struggle for the reconstruction of black solidarity but without 'race' as a viable biological concept. ${ }^{30}$

\section{Kairos theology and the post-apartheid relevance of black theology in South Africa}

The third wave of black theology has been given impetus by the rebirth of kairos theology in South Africa. It was the rediscovery of the role black theology played in the restoration of black South Africans' human dignity and black identity that was behind this rebirth. The criticism of kairos theology is also a criticism of black theology in South Africa that it:

was important for the common good in the quest for liberation in the struggle against apartheid, but is found greatly wanting in its resourcefulness for the public good in the quest for reconstruction and transformation in contemporary struggles. (Le Bruyns 2012:4)

One of the leading exponents of the third wave is Itumeleng Mosala (cf Kee 2008:87). He advocates that black theology has to progress beyond two alternatives: (a) the reading of a textthe aim of which is simply to recover the meaning of the text, and (b) an existential (spiritual) privatised internalising of it (cf Kee 2008:89). For Masala, black theology can be an instrument of liberation only if it has freed itself from the assumptions and basic presuppositions it shares with the ruling classes. South African black theology which has liberated itself from the Marxist class struggle can be an

29. Shelby (2001:266) argues that "black solidarity can survive the well-known critique of racial/ethnic essentialism; it can be sustained despite the loss of "race" as a viable biological concept'.

30. Black theology can survive despite the loss of 'race' as a viable biological concept if it recovers black solidarity. 
instrument of liberation theology. For Mosala, the only valid hermeneutical starting point for a black theology is the social, cultural, political and economic world of the black working class and peasantry. In the post-apartheid South Africa, theological discourse may need to be re-appropriated and made responsive to new challenges 'for the kind of public impact and critical participation that the times demand' (Le Bruyn 2012:5). A public theology is needed that addresses 'the much-needed dimensions of contextuality, criticality and change' (Le Bruyn 2012:5). The most basic presupposition of black theology is about human dignity and black identity, which sets it apart from liberation theology.

\section{Colonisation and the relevance of post-apartheid black theology}

It is because of the continuation of imbalances of power, the exaggeration of conflicts among tribal peoples by colonisers and the replacement of white rulers by black rulers without those at the bottom experiencing very little change in their economic freedom which indicates that there is still a need for a black theology or a theology of the oppressed. The result of a manipulation of historical and biblical narratives by the oppressors, the white colonisers and the exchange of the white elite with a black elite have simply been the exchange of oppressors: the oppressed have become the oppressors. The value of the black theology of South Africa is that it makes it possible for Africans to deal with the devastating effect of colonialism that has plagued newly independent nations while addressing the divisions remaining among peoples on the African continent. Black theology united different African ethnicities and gave to South African people a sense of a cohesive unity and identity. Black theology provides a communal sense of identity that is able to bring about a cohesive sense of national identity in contexts of post-colonialism, tribalism, ethnocentrism and the new racism of xenophobia.

\section{Xenophobia}

Black theology in South Africa united tribal ethnicities under the banner of the common cause of the struggle. In the absence of a unifying cause an attitude of $u$ s and them can develop in a climate of perceived limited economic resources. Xenophobia broadly means a fear of what is unfamiliar, particularly of the other who is different and therefore perceived as a threat. It is as a result of this that an attitude of $u s$ and them is perpetuated. It is a response to fears held by the hegemonic majority to the possibility of a loss of identity that enforces a cultural hegemony by controlling people's worldview that depends upon material force, economic relations and cultural hegemony. It is the aggressive oppression of the other based on a preservation of a perceived threat to national identity. Xenophobia is about the loss of respect of diversity of mankind and so fundamentally about a loss of human dignity. The only solution to the problem is to effectively teach and preach about human dignity within schools, tertiary education institutions, cities, townships, informal settlements and churches.

\section{The hermeneutics of black theology}

One of the most enduring legacies of South African black theology is its hermeneutics (cf Maluleke 2000:31). A prerequisite for a black theology is a contextual reading of the scriptures. A return to the most traditional meaning of hermeneutics in which the most basic reading and interpretation of a message is that the human beings' search for identity and significance is needed. The Exodus for the people of Israel was an identity-forming narrative and not primarily a liberation narrative. The Israelites had been stripped of their identity and so they had been disconnected from their Jewish roots. The Exodus is a central biblical narrative in the history of Israel. Israel's identity as a nation was bound up with Yahweh, who was the God of the Hebrews. Yahweh introduces himself to Moses as 'The Lord, the God of your fathers, the God of Abraham, of Isaac, and of Jacob' (Ex 3: 6) and identifies himself with them as an oppressed people. 'In the exodus, not only does God reveal himself in the midst of Israel's slavery, his revelation (as the "I $\mathrm{am}^{\prime}$ ) also discloses a new history of future for Israel' (Katongole 2011:111). It was in Israel's discovery of who God was, the 'I am', that they learned who they were and discovered their identity as the people of God. The liberation of Israel was secondary; their rediscovery of their identity was primary. The redemption of Israel was an identityforming act by God. God is portrayed as the God who hears the cries of his oppressed people: 'And now behold, the cry of the people of Israel has come to me, and I have also seen the oppression with which the Egyptians oppressed them' (Ex 3: 9). God reveals himself as the God of Israel for the sake of the nations. He does not take the side of the oppressed, Israel against the oppressors, Egypt: 'The God who chose Israel out of the nations remained always the God of all the nations' (Niles 1962:250). Niles continues:

Such a conception of Israel's life and mission demanded on the one hand that it guards its identity in the world, and on the other hand that it serves the world towards which its mission was set. (Niles 1962:250)

Yahweh's unique purpose with Israel gave to the nation a special identity, a unique mission which set it apart from all other races, cultures, tribes, families and nations. God wanted to liberate the Egyptians from their fears and dread, which caused them to oppress the people of Israel as much as $\mathrm{He}$ wanted to liberate Israel. The Egyptians, however, did not see themselves in need of liberation. But human beings are continuously in need of liberation because we are constantly enslaving ourselves. One of the conditions of God's covenant relationship with Israel was that they would not oppress the foreigner. ${ }^{31}$ God was particularly concerned with just social relationships and justice among those who claimed God to be on their side. He did not tolerate or condone injustice among anyone who appropriated his name. After each exile God led His people to a renewed understanding of human dignity and their identity.

31.The "Noahic code' (Gn 9:1-7) is made up of practical, moral/ethical articles; it affirms the inherent value of the human person $(\mathrm{Gn} 9: 5)$ and it links criminal law to
metaphysical and theological considerations ( $\mathrm{Gn} 9: 6)$. A criminal act is an offence against the dignity of man and to the honour of God. 
In the book of Nehemiah and Ezra, Israel's identity as the people of Yahweh is reshaped and rediscovered. The period of renewal began with a call by the prophets for the people to renew their covenant relationship with God and so to rediscover their identity. Israel, as God's covenant people, was to participate in Yahweh's universal purpose for the whole world.

The central biblical narrative in American black theology $y^{32}$ and liberation theology is the Exodus. In these theologies the Exodus is a definitive narrative that serves as a source for overcoming oppression, which is understood as political victimisation. Just as God liberated Israel from Egypt, so the Bible's message calls people out of bondage (cf Yarborough 2011:274). The Exodus and Old Testament 'prophets call for social justice in ways that pave the way for similar outcomes now' (Yarbrough 2011:274). Boesak 'pursues the theme of the Exodus, but he is careful not to argue that 'God has taken sides in the South African situation' (Kee 2008:84). The Exodus in South African black theology is not appropriated by the blacks against the whites as though God was on the side of the blacks. In the South African context God is on the side of the righteous, that is those who are motivated by the love of God and neighbour.

Bosch suggested that we should focus more on the idea of love than justice because that will prevent our prophetic mission from becoming purely political (Bosch 1992:402-403). Love precedes all theology: 'Christian love as correctly lived excludes no one and loves everyone' (Aguilar 2009:116), whether the oppressed or the oppressor.

\section{A hermeneutic of love and justice}

Gutiérrez speaks of a theology of a 'second act' and for this reason Aguilar proposes a hermeneutics of a 'second act', 'not only because it is a process of interpretation of an already past event but also because the sole principle of Christian interpretation is love' (Aguilar 2009:35). A theology of liberation needs to emphasise 'a second step' to remain on Gutiérrez's path of theology (cf Aguilar 2009:18). 'Love is the first and only central act in the silence of God' (Aguilar 2009:35). It is the centrality of God's love denied by human beings in apartheid that becomes the only possible theology. Ricoeur (1991) makes the history of humanity itself rather than God's involvement in the history of humanity central to the process of interpretation. It is to this interpretative framework of Ricoeur that the views of Gutiérrez of people's understanding of the place and mode of God's Presence in their lives and in the process of history as 'a very changeable locus theologicum' is added (cf Aguilar 1998:64). It makes human beings the central players, although God plays a part in it. The biblical texts of Israel's experience of its exile are brought into dialogue by Aguilar to answer the question of the absence or presence of God in the midst of trauma: 'The meaning of the biblical text comes from the contextual

32.'They (blacks) were not fully African, nor were they fully American. The lack of resolution of this identity question was at the soul and deep being (heart) of blacks. This this identity question, was at the soul and deep being (heart) of blacks. This led Ron Karenga and Le Rol Jones to embark on dealing with these questions of identity (Ndalamba 2010:29). Identity was at the root of South African black theology whereas American black theology advocated primarily the emancipation of Black Americans. reading of an appropriate text and not from extrapolating and manipulating sentences in order to prove the point already assimilated' (Aguilar 1998:71):

The contextual reading of the Scriptures is essential because it takes into account the ever changing relationship between human beings and God in an unpredictable historical setting that can only be expressed as the now and the future to come. (Aguilar 1998:71)

For Gutiérrez, the presence or absence of God is a biblical dialectic that he refers to as 'the tension between God's visibility and invisibility, between God's obvious and hiddenness' (cf Aguilar 1998:56). Gutiérrez connects God's love to his presence and the presence of God's kingdom to the acceptance of God's demands; in his view, the kingdom of God is dependent upon justice: 'God's presence or absence is therefore related to people's attitude towards others, especially those in need' (1998:58). This, however, makes God's presence or absence dependent upon justice as the central concern. God is equally present with the oppressed and the oppressor, the just and the unjust, the loving and the unloving, as there is no human action or omission or attitude upon which God has made his presence or absence dependent. God is as present with his people during their sojourn in exile as when they reside in the land of Israel.

Israel's injustice was the result of forgetting their covenant with God, the love of God for His people, but God never forgot His people. The exploitation and oppression of the poor was symptomatic of a breakdown of Israel's covenant relationship with God. It is as God's love for his people is rejected that God's will and justice are eclipsed. It was because Israel did not live in a covenant relationship with a loving God and did not perceive God to be a God of justice that Israel began to oppress others. Love and justice are closely related: 'Love is the root of justice, and doing justice is a way of loving' (Bowh Si 2008:92). In other words, if love and justice go together in the praxis of black theology, there will be both liberation and reconciliation that will include not only the liberation of the oppressed but also the repentance by the oppressors (cf Bowh Si 2008:93).

It is the reorientation of black theology to biblical concepts that distinguishes it from liberation theology. ${ }^{33}$ Forrester makes the point that they are inseparably bound together: 'Love without justice is in danger of becoming sentimental and irrelevant; justice without love easily becomes judgmental and uncaring' (1997:77-79). The prophet Jeremiah reminds the people of God as covenant people to show compassion and practise justice towards one another. Salvation has therefore been promised to all those who search for the kingdom and its love and justice in fulfilment of the covenant's demand for love and justice. It is a recognition of God's radical love through the incarnation of a personal God that became visible in the Person of His beloved Son, Jesus Christ, which is central to the covenant. The crucifixion of Jesus of Nazareth remains at the centre of the loving plan of God. The

33.Black theology has been reoriented by Boesak and Tutu to include human dignity and reconciliation. 
God of life is present in moments of complete human annihilation and loss of human dignity. God's love is for the oppressed but also for the oppressors. It is through the love of the oppressed towards the oppressors, which is possible only if the idea that they are victims is overcome, that both the oppressed and the oppressors can experience freedom. God's love is all-embracing; it seeks to set everyone free.

\section{Black theology - a theology of dignity and identity, not a materialist theology}

It has been proposed that black theology is materialist theology, but it is liberation theology that is materialist. Although South African black theology was about economic liberation, it is only in the context of a rediscovery of human dignity and identity that there can be true economic freedom.

Liberation theology which performs a Marxist analysis deals only with an analysis of class; black theology has been expanded to include culture and race. The hermeneutical method of liberation theology makes use of a materialist reading, aims at a materialist history of Israel and an African materialist history: 'The social, cultural, political and economic world of the black working class and peasantry constitutes the only valid hermeneutical starting point for a black theology of liberation' (Mosala 1989:21, in Kee 2008:89). ${ }^{34}$ In liberation theology, God takes sides with the poor against the rich and the theology becomes a weapon in the hands of the oppressed. Black theology does not depict God as taking sides, but rather God as liberating both the poor and the rich - the rich are in need of liberation as much as the poor.

While liberation theology struggles for class and economic freedom, black theology is a theology of black emancipation, culturally, socially, politically and economically. The mantra of liberation theology is found in Jesus' first sermon in Nazareth: 'The Spirit of the Lord is upon me, because he has anointed me to preach the good news to the poor' (Lk 4: 18). Luke is read as a champion of the poor, captives and oppressed. A liberation theological reading of Luke 4: 18-19 and 20-28 eclipses the fact that Jesus confronts the false Jewish expectations which were tied to a Jewish nationalism and a struggle for liberation when Jesus identified with the Jewish people's struggle for liberty and their oppression, '[a]ll the people spoke well of him and marveled at the gracious words that were coming from his mouth' (Lk 4: 22). The picture changed suddenly and the Jews were 'filled with wrath' (Lk 4: 28) when Jesus also identified himself with their oppressors. Theology has a responsibility to both the oppressed and the oppressors to break the cycle of oppression so that both the oppressed and the oppressors experience freedom.

In South Africa it was through black theology that churches became a key source of opposition to the authoritarian government. The shared material interests of State and Church were reinforced by close relationships between

34.The contribution of Mosala is that the importance of working-class blacks be understood comprehensively - as cultural, political and economic - and that the struggle against such domination be consciously and deliberately directed at all these levels. church leaders and government officials. In South Africa the Christian message broke down the walls of the attitude of $u s$ and them, a distinction based on ethnic characteristics, language or religion that leads to one group being favoured: 'This grouping of us and them assumes that there are no good people among them while all of us are acceptable ... The [former have] more access to goods, status, power or resources while the other people are marginalised' (Aguilar 1998:24).

\section{Black theology a source of empowerment}

The rediscovery of an African identity through the first two waves started by Steve Biko and Allan Boesak gave to black theology in South Africa a unique identity separate from American black theology and liberation theology. Black theology in South Africa became a theology of empowerment instead of one that existed as a reaction to racism or apartheid. For Biko the accent was on the human being rather than on power (cf Du Toit 2008:35). Black theology is that of the voiceless and powerless, not exclusively of the poor and marginalised. Powerlessness is the inability to control what happens, the inability to plan for the future, and the imperative of focusing on the present. It was while a new black wealthy class emerged in South Africa after 1994 and black South Africans gained access to economic and political resources that the cycle of oppression continued, but through the new black elite. That elite has crossed the line to join those who held power and privilege.

It is because the cycle of oppression was not broken that the oppressed blacks have themselves become the new oppressors - 20 years after the apartheid struggle ended, the language of apartheid is still being used by the oppressed in the role of the oppressor to justify personal agendas of gain. The black theology that gave a new confidence and selfperception to black South Africans that they had control over their destiny has been replaced by agendas of personal greed.

Black theology in South Africa has never had racism as its agenda. The roots of oppression lie deeper than racism so that while the end of apartheid is a welcome development along the way, it is not the end. It involves much more than the idea that the perception of inferiority has simply been replaced by access to economic and political resources. Rather, it is the ongoing stereotypes of the other as inferior that formulate a mythical or ideological construct which provides a rationale or justification for legal, social and political equality. This in turn gives the false impression that all problems of inequality will simply disappear with the attainment of economic and political equality. The unjust discrimination and oppression will simply continue and new oppressors will replace the old because the deeper-seated human dignity and identity has not been sufficiently addressed.

The third wave is a new awareness of the agency of ordinary marginalised Africans (cf Maluleke 2000:28) and the espousal 
of a multiplicity of African identities. ${ }^{35}$ There can be no advocacy of a single African identity because African culture is extremely diverse. But, according to Maluleka, ' $t$ the agency of African Christians and the African poor is being rediscovered, explored and respectfully interpreted' (2000:31). ${ }^{36}$ When articulating a multiplicity of African identities, nothing about African culture or the African poor must be romanticised.

It was the common struggle against a system which robbed people of their human dignity, identity and rights that unified them. When values of human dignity, identity and rights are upheld, the same fervour of a generation that grew up in a post-apartheid era, the South African nation will once again be unified, and in this black theology can play a central role if it takes up the challenge.

\section{Conclusion}

The essence of the black theology that developed in South Africa was a struggle for human dignity, what it means to be human and to know one's identity. This clearly set it apart from liberation theology: black theology is a grassroots theology that does not simply act on behalf of the poor and the marginalised but draws them into the struggle on the grounds of human dignity and identity. It is a theology that confronts imbalances of power and abusive power structures in order to restore human dignity and identity. The reorientation of black theology to the biblical concepts of repentance, reconciliation, forgiveness, love, justice and the poor distinguishes it from liberation theology, which is oriented towards freedom, liberation, justice and the struggles of the poor interpreted almost exclusively through the Marxist theory of class struggle. On the contrary, black theology struggled against the construct of one people or ethnic group as superior and the dehumanisation of the other, who is viewed as inferior. Black theology has a responsibility to both the oppressed and the oppressors to break the cycle of oppression so that the oppressed do not become the oppressors. What is required is a return to the most traditional of meanings of hermeneutics in which the most basic reading and interpretation of a message is the human being's search for dignity- and identity. The hermeneutic interprets the Exodus, the return from the Exile and other biblical events as dignity- and identity-forming narratives rather than narratives of liberation. It is because human dignity and identity have been disregarded in post-apartheid South Africa that now more than everthere is a need for a black theology.

35.'Africans have always been agents, never "simply victims, wallowing in self-pity"; they have always exercised their agency in struggles for survival and integrity. However their agency has not always been recognized, let alone nurtured' (Maluleke 2000:28),

36.'There is a new realisation that the African poor, African Christians and Africans in general are not without resources, intellectual, material and spiritual resources for survival and resistance' (Maluleke 2000:31).

\section{Acknowledgements Competing interests}

The author declares that he has no financial or personal relationships that may have inappropriately influenced him in writing this article.

\section{References}

Aguilar, M.I., 1998, The Rwanda Genocide: Call to deepen Christianity in Africa. AMECEA Gaba, Kenya.

Biko, S., 2004, I write what I like. Picador Africa, Johannesburg.

Boesak, A., 1978, Black Theology Black Power, Mowbrays, London.

Boesak, A., 1984, Black and Reformed: Apartheid, Liberation and the Calvinist Tradition, Skotaville Publishers, Johannesburg.

Bowh Si, O.B., 2008, 'Mission as transformation: An exploration of the relationship between mission and development', International Review of Missions 97(584/585):91-102, January/April.

Buthelezi, M. 1974. 'An African Theology or a Black Theology?' in Basil Moore (ed), The Challenge of Black Theology in South Africa, John Knox Press, Atlanta.

Davidson, M. del G., 2006, The Rhetoric of Race: Towards a Revolutionary Construction of Black Identity. Publications de la Universitat de València, València.

Du Toit, C., 2008, 'Black consciousness as an expression of radical responsibility: Biko an African Bonhoeffer', Religion \& Theology 15(1), 25-52. Koninklijke Brill NV, Leiden.

Forrester, D.B., 1997, Christian Justice \& Public Theology, Cambridge University Press.

Katangole, E., 2011, The Sacrifice of Africa: A Political Theology for Africa, W.B Eerdmans, Grand Rapids.

Kee, A., 2008, The Rise and Demise of Black Theology: Reclaiming Liberation Theology, SCM Press, London.

King, M.L. Jr., 1967, Where do We go from Here: Chaos or Community, Harper \& Row, New York.

Le Bryuns, C., 2012, 'The rebirth of kairos theology? A public theological perspective', Brazil-South Africa Consultation on Citizenship and Interculturality, vol. 23, UNISA, Pretoria.

Longman, T., 2010, Christianity and Genocide in Rwanda, African Studies, Cambridge University Press, Cambridge.

Maluleke, TInyiko, S., 1995, 'Black theology lives! On a permanent crisis', Journal of Black Theology in South Africa 9, 1(May):1-30.

Maluleke, T.S., 2000, 'The rediscovery of the agency of Africans: An emerging paradigm of post-Cold War and post-apartheid black and African theology', Journal of Theology of Southern Africa 108, 19-37.

Mbiti, J.S., 1974, 'An African views American black theology', Worldview 17, 41-44.

Moore, B., 1973, Black theology: The South African voice, C. Hurst \& Company, London.

Mosala, I.J., 1989, Biblical hermeneutics and black theology in South Africa, Eerdmans Publishing Co., Grand Rapids.

Motlhabi, M., 2008, African theology/black theology in South Africa: Looking back, moving on, University of South Africa, Pretoria.

Motlhabi, M., 2009, 'Phases of black theology in South Africa: A historical review', Religion \& Theology 16, 162-180.

Ndalamba, K.K. 2010. 'In search of an appropriate leadership ethos: A survey of selected publications that shaped the black theology movement', MTh thesis, University of the Western Cape, Bellville.

Niles, D.T., 1962, Upon the Earth: The mission of God and the missionary enterprise in the churches,: Mcgraw-hill, New York.

Nothwehr, D.M., 2010, 'Defining "racisms": Understanding our globalised, terrorised ecologically threatened world', in O.U. Kalu, P. Vethanayagamony \& E.K.-F. Chia (eds), Mission after Christendom: Emergent themes in contemporary mission, pp. 115-127, Westminster John Knox Press, Louisville.

Pinn, A.B., 1998, Varieties of African American religious experience, Fortress Press, Minneapolis.

Pobee, J.S. 1979, Towards and African theology, Abingdon, Nashville.

Ricoeur, P., 1991, On Paul Ricoeur: Narrative and Interpretation, University of Chicago Press, London \& New York.

Shelby, T., 2001, 'Foundations of black solidarity: Collective identity or common oppression?' Ethics January, 231-266.

Yarborough, R.W., 2011, 'New Testament studies in Africa', in A.J. Köstenberger \& R.W. Yarborough (eds), Understanding the times: New Testament studies in the 21st century, pp. 249-276, S. Wheaton, Crossway.

West, C., 1982, Prophesy deliverance: An Afro-American revolutionary Christianity, Westminster Press, Philadelphia.

Woods, D., 1987. Biko, Holt, New York. 